\title{
USE OF SOCIAL NETWORKING SERVICES AMONG SLOVENES AROUND THE WORLD
}

\author{
Damjan FUJS', Simon VRHOVEC"
}

COBISS 1.01

\section{ABSTRACT \\ Use of Social Networking Services among Slovenes around the World}

The authors conducted a survey of online groups on Facebook $(\mathrm{N}=270)$ and a survey of Slovenian migrants $(\mathrm{N}=629)$ to gain insight into the use of social networking services (SNSs) during different phases of the migration process. SNSs can help migrants establish new relationships with migrants in the destination country, which may help them to cope with periods of loneliness in the post-migrant phase. Online groups are an important source of information on the destination, aiding informed decision-making in the pre-migrant phase. Migrants in the post-migrant phase may have lower privacy concerns and perceive higher regulatory protection of their privacy than in the settled phase.

KEYWORDS: social networks, Facebook, migrants, social networking services

\section{IZVLEČEK}

\section{Uporaba storitev socialnih omrežij med Slovenci po svetu}

Da bi dobila vpogled $v$ uporabo storitev socialnih omrežij (SSO) med različnimi fazami migracijskega procesa, sta avtorja pregledala spletne skupine na Facebooku ( $\mathrm{N}=$ $270)$ in izvedla anketo med slovenskimi migranti $(\mathrm{N}=629)$. SSO pomagajo migrantom vzpostaviti nova razmerja z migranti v namembni državi, kar jim lahko pomaga med spoprijemanjem z obdobji osamljenosti v postmigrantski fazi. Spletne skupine so pomemben vir informacij o destinaciji in pomagajo pri informiranemu odločanju v predmigrantski fazi. Migranti imajo v postmigrantski fazi manjše skrbi glede zasebnosti in zaznavajo višjo regulativno zaščito svoje zasebnosti kot $v$ ustaljeni fazi. KLJUČNE BESEDE: socialna omrežja, Facebook, migranti

B.Sc. in Information Security, M.A. in Criminal Justice and Security; University of Maribor, Faculty of Criminal Justice and Security, Kotnikova 8, Sl-1000 Ljubljana; PhD student at University of Ljubljana, Faculty of Computer and Information Science, Večna pot 113, SI-1000 Ljubljana; damjan. fujs@fri.uni-lj.si

\| PhD in Computer and Information Science, Assistant Professor; University of Maribor, Faculty of Criminal Justice and Security, Kotnikova 8, SI-1000 Ljubljana; simon.vrhovec@um.si 


\section{INTRODUCTION}

Due to the development of the internet and social networking services (SNSs), future generations will very likely find it hard to imagine that in the past, letters traveled several months or years to reach their intended recipients. SNSs today provide billions of people (Statista 2020) with ongoing and highly reliable connectivity (Bieniasz, Szczypiorski 2019), fast and easy access to communication, sharing thoughts with others, and several other activities, such as entertainment, education, building human relationships and political activities (Grčić et al. 2017; Ortiz Ángeles et al. 2017; Bustos López et al. 2018; Sivasangari et al. 2018). It is well-known that from the beginning of emigration, as they have founded their communities, Slovenian migrants have been able to organize themselves for cultural, ethnic, and religious affiliation (Kuzmič 2001; Kalc 2018). Using the internet and being online can, therefore, help and enhance the preservation of the cultural and ethnic heritage of Slovenes around the world (Hladnik 2008; Lenarčič 2020).

However, the use of communication technology and SNSs among Slovenian migrants has rarely been studied (Lenarčič 2020). Rather, the research has focused either on the internet in general (Hladnik 2008) or specific websites (Meden 2007). For example, Meden (2007) reviewed existing and representative web pages of Slovenes around the world. In the last two decades, however, no new research has emerged to address the topic of the use of SNSs by Slovenian migrants. To fill in this gap, we conducted one of the first studies on the use of SNSs among Slovenian migrants. The migration process can be divided into four key phases: pre-migrant, travel, postmigrant, and settled phase (Lenarčič 2020). We posit the following research questions to study the use of SNSs among Slovenian migrants in these phases:

RQ1: Which topics related to the pre-migrant, travel, post-migrant, and settled phases do Slovenian migrants and would-be migrants discuss in online groups on Facebook related to Slovenes around the world?

$R Q 2$ : What are the differences in the perceptions regarding security and privacy on SNSs of Slovenian migrants in post-migrant and settled phases?

We have organized this paper as follows. First, we lay out the theoretical foundations of the study in the section Migration and Social Networking Services. In the section Research Methodology, we describe in detail the employed research design and methods. We first describe the data collection and analysis procedures for the survey of online groups on Facebook related to Slovenes around the world and then for the survey of Slovenian migrants. The section Topics Discussed in Online Groups presents the results of the qualitative analysis of user posts in studied online groups, and the section Perceptions Regarding Social Networking Services presents the results of the quantitative analysis of the perceptions of Slovenian migrants regarding SNSs. We also discuss the implications of the results within these sections. 
In the section Concluding Remarks, we outline the overall impact and limitations of our study and provide suggestions for future research.

\section{MIGRATION AND SOCIAL NETWORKING SERVICES}

The ubiquitous presence of technology in our everyday lives has blurred the physical limits of our social endeavors as SNSs offer us a variety of social functions, such as providing social and emotional support, maintaining relationships between people and obtaining information on various matters, regardless of where we are (Joinson 2008; Atanasova, Petrič 2014; Shahriari et al. 2017). Today's always-connected online societies affect not only the migration process but the concept of migration itself (Lenarčič 2020). Traditional migrants have reshaped into connected or online migrants, who can essentially migrate to the destination country together with their social networks. This possibility enables them to keep close to their homeland and enables the emergence of new phenomena, such as digital diasporas (Oiarzabal, Reips 2012; Lenarčič 2020). Online migrants may, therefore, eventually establish a bicultural identity (Reips, Buffardi 2012) and maintain or strengthen their ties with two homelands in parallel.

Although SNSs can help in keeping migrants close to their homelands, they can also hinder their motivation to establish new social relationships with local residents in destination countries, which may, in turn, affect their well-being (Zhang et al. 2019; Lee et al. 2020). A lack of motivation to engage in relationship building with local residents coupled with language and other barriers may result in the social loneliness of migrants despite having a sizeable social network, frequent contacts, and good family relationships (ten Kate et al. 2020). Social and emotional loneliness may stem from high expectations about social relationships and a lack of a sense of a community (Ibid.). Cultural loneliness caused by not feeling understood in a different cultural context may also emerge (Ibid.). In some cases, migrants may also experience loneliness due to the separation from social networks in their homeland despite the existence of SNSs (Lee et al. 2020).

Migration also affects the people who stay behind. For example, the women who remain as their family members migrate internationally are at higher risk for depression (Edelblute, Altman 2020). Social support and relationships, coupled with the frequent use of SNSs, may reduce the odds of depression among them (Ibid.). Migrants also offer some insight into foreign countries to members of their social networks, which may affect their decision to migrate as well (Nelson, Marston 2020). Although the migrants' social networks facilitate the spread of job information, only the native social network in a destination country seems to provide migrants with information on better job opportunities (Bolíbar 2020; Wang 2020). It may be interesting to note that the less accurate the information passed to a potential migrant, the greater its impact (Nelson, Marston 2020). Vague success stories seem to attract 
people to migrate more than accurate information on the difficulties of finding a job and learning a foreign language (Ibid.). Accurate information from trusted sources, such as migrated family members and friends, may, therefore, discourage would-be migrants from migrating themselves (Lenarčič 2020).

The use of SNSs by migrants may also give rise to unwanted phenomena, such as long-distance nationalism, which may fuel inter-ethnic conflicts between migrants and the local population (Oiarzabal, Reips 2012). Although migrants tend to be less politically involved (McKay 2020), SNSs are often a vital source of political information (Ajder 2018). SNSs may even be leveraged by authoritarian regimes to build soft power resources in migrant communities and try to influence events in other countries (Golova 2020).

To study the use of SNSs in the context of migration, we lean on the four phases of the migration process proposed by Hiller and Franz (2004) and Lenarčič (2020). The pre-migrant phase covers the decision-making process of potential migrants. It involves gathering information on the destination and how to reach it as well as establishing contacts with individuals and communities in the destination country to facilitate the migration (Hiller, Franz 2004; Lenarčič 2020). The travel phase typically involves seeking real-time information related to reaching the intended destination. It is especially relevant for illegal migrants (e.g., navigation, safe points for crossing a border, weather forecasts, etc.) (Lenarčič 2020). The post-migrant phase is the time since reaching the destination country until settling there and may be arbitrarily set to five years, even though it may be significantly shorter or longer for individual migrants (Hiller, Franz 2004; Lenarčič 2020). In this phase, migrants try to integrate into the new social environment while typically keeping in touch with people and culture in their homeland (Lenarčič 2020). In the settled phase, migrants usually fully adapt to the new environment and try to keep or re-establish a lost connection to the homeland (Hiller, Franz 2004; Lenarčič 2020).

\section{RESEARCH METHODOLOGY}

This paper reports on two separate but complementary studies. The first is a survey of online groups on Facebook related to Slovenes around the world to gain insight into the topics discussed by Slovenian migrants. The second is a survey of Slovenian migrants to determine the differences in their perceptions regarding SNSs in the post-migrant and the settled phases.

\section{Survey of Online Groups on Facebook Related to Slovenes around the World}

To answer RQ1, a survey of online groups on Facebook related to Slovenes around the world was conducted between April 11 and June 12, 2019. In this paper, we consider an online group any of the following: a Facebook group, a Facebook page, or a 
Facebook profile. Although there are significant differences in their functionalities, we considered all of them as online groups due to their primary objective, i.e., to provide a platform for connecting Slovenian migrants.

A Facebook user can typically join Facebook groups by sending a request. The group's administrators or moderators process and either confirm or reject the request to join it. Administrators have full control of a group, while moderators have a limited set of functionalities (e.g., they cannot delete a group). Although it is possible to set up a Facebook group without the need for new members to first send a request, most groups require the approval of the group administrator or moderator. We noticed an issue with non-responsive administrators or moderators, as it can take a long time before someone is accepted into the group. This is especially an issue for groups with a single administrator. All group members can post into the group, which forms a kind of group chat. Individual posts can be pinned by administrators or moderators to increase their visibility.

Facebook pages are typically dedicated to certain topics. Unlike Facebook groups, Facebook pages cannot be joined. Instead, users can only like them. Anyone can post on a page without ever liking it. The major difference is that user posts are much less visible on pages than in groups. The main content is provided by page owners (or users with other roles), and casual visitors can easily overlook user posts at the side of the page.

Facebook profiles are meant for natural persons. Nevertheless, profiles can be used to form online groups. One can connect with a profile by adding it as a friend. A Facebook profile can publicly (e.g., through public posts on its wall) or quasi-publicly (e.g., a group chat with most or all friends of a profile) interact with others. Essentially, a Facebook profile is equivalent to a Facebook page meant for natural persons instead of businesses, associations, and other communities.

By using a combination of different keywords, such as Slovenes in, Slovenians in, Slovenian home, and Slovenci v, and our own intuition as researchers, we searched for the relevant online groups on Facebook. We identified a total of $N=270$ Facebook groups, pages, and profiles (127, 140, and 3, respectively). Table 1 shows the top ten online groups by their size.

Table 1: Top ten online groups by size in 2019

\begin{tabular}{cccc}
\hline Online group on Facebook & Type & Launched & Num. of users \\
\hline Slovenci v Avstriji & Facebook group & 2013 & 24,575 \\
\hline Slovenci v Londonu & Facebook group & 2007 & 10,145 \\
\hline Slovenci v Nemčiji & Facebook group & 2010 & 7,279 \\
\hline Slovenci v Švici & Facebook group & 2008 & 6,396 \\
\hline Study Planet Slovenia & Facebook page & 2014 & 6,144 \\
\hline
\end{tabular}




\begin{tabular}{clll}
\hline Slovenci v Avstraliji & Facebook group & 2008 & 5,446 \\
\hline Slovenci v Berlinu & Facebook group & 2010 & 4,251 \\
\hline Slovenci na Nizozemskem & Facebook group & 2008 & 4,013 \\
\hline Slovenian Genealogy (Genealogy2000) & Facebook group & 2011 & 3,796 \\
\hline Slovenci na Filipinih & Facebook page & 2016 & 3,334 \\
\hline
\end{tabular}

We first screened online groups for their characteristics. The collected data included the name of the online group, type, target country, creation date, number of members, hyperlink, and screening date. Next, we qualitatively analyzed the content of the most recent posts in individual online groups in a non-intrusive way. We coded the posts to identify emergent themes based on the data, providing illustrative quotes to better describe the themes. Finally, we conducted a cross-group analysis to consolidate the findings.

We have preserved the names of the online groups on Facebook, which allows the readers to find them directly. Some online groups have been on Facebook for a long time. For example, the oldest online group (namely, Slovenians in the UK) was launched on June 6, 2007. During their existence, some online groups have changed their names or key themes. Online groups can also become inactive. Some of them only temporarily but others seemingly permanently. For example, the most recent activity in some of the studied online groups was in 2014 (i.e., five years before our study).

\section{Survey of Slovenian Migrants}

To answer $R Q 2$, an online survey has been conducted among members of online groups on Facebook related to Slovenes around the world (e.g., Slovenes in Austria, Slovenes in Australia, Slovenes in Munich, Slovenian Union of America, Slovene National Benefit Society, etc.) using snowball sampling for practical reasons, such as the ability to comment, share, ask questions, and observe responses of other SNSs users. The survey was hosted on the $1 \mathrm{ka}$.si online platform from February to June 2019. Respondents were advised that participation was voluntary, that their anonymity would be protected, that data would only be reported only in aggregated form, and that collected data would only be used for research purposes.

A total of 633 respondents completed the survey. After excluding poorly completed responses, we were left with $N=629$ useful responses. The age of the respondents ranged from 16 to 110 years $(M=41.5, S D=15.9)$. Table 2 presents other demographic characteristics and the duration of residence. 
Table 2: Demographic characteristics of the sample and duration of residence

\begin{tabular}{lll}
\hline Gender & $N$ & $\%$ \\
Female & 376 & 59.8 \\
Male & 247 & 39.3 \\
N/A & 6 & 1.0 \\
\hline Status & & \\
Student & 81 & 12.9 \\
Employed & 425 & 67.6 \\
Not employed & 36 & 5.7 \\
Retired & 75 & 11.9 \\
N/A & 12 & 1.9 \\
\hline Education & & \\
Completed high school or less & 89 & 14.1 \\
Bachelor's degree & 211 & 33.5 \\
Master's degree & 229 & 36.4 \\
PhD degree & 91 & 14.5 \\
N/A & 9 & 1.4 \\
\hline Duration of residence & & \\
Since birth & 236 & 37.5 \\
More than fifteen years & 84 & 13.4 \\
Ten to fifteen years & 36 & 5.7 \\
Five to ten years & 69 & 11.0 \\
One to five years & 131 & 20.8 \\
Less than one year & 58 & 9.2 \\
N/A & 15 & 2.4 \\
\hline
\end{tabular}

Based on a respondent's duration of residence, we determined the migration phase. We considered respondents with up to five years of residence to be in the postmigrant phase, while those with over five years of residence to be migrants in the settled phase. Most respondents in both migration phases were female, although the share was higher in the post-migrant than in the settled phase (65.6 and 57.6 percent, respectively). Most respondents in both phases were employed (70.4 percent in the post-migrant and 68.2 percent in the settled phase). More respondents were students in the post-migrant than in the settled phase (21.2 and 9.6 percent, respectively), indicating a noticeable share of Slovenes studying abroad. Unemployed respondents in the post-migrant phase were more than those in the settled phase, albeit both with relatively small shares ( 8.5 and 4.7 percent, respectively). All retirees were in the settled phase. Respondents in both migration phases had comparable formal education. Most respondents have a bachelor's or master's degree. The share of respondents with a $\mathrm{PhD}$ degree seems rather high, suggesting a brain drain.

Respondents were from 55 countries around the world, as presented in Table 3. The sample seems to be dominated by respondents from the United States (20.7\%). 
Neighboring countries with Slovenian minorities (e.g., Italy, Austria), countries with notable Slovenian diaspora (e.g., Argentina, Canada, Australia), and traditional destinations in the EU for migrants for economic reasons (e.g., Germany, Switzerland, UK) are also well-represented. However, their share does not appear to be much higher than in other countries. Such numbers suggest that these countries may be underrepresented in our sample.

Table 3: Country of residence

\begin{tabular}{cc}
\hline $\mathbf{N}$ & Countries \\
\hline $130-132$ & United States \\
\hline $37-39$ & Argentina \\
\hline $34-36$ & Canada, Slovenia \\
\hline $31-33$ & Australia, Germany \\
\hline $25-27$ & United Kingdom \\
\hline $22-24$ & Austria \\
\hline $19-21$ & Croatia \\
\hline $16-18$ & Belgium, China, Hungary, Ireland, New Zealand \\
\hline $13-15$ & Serbia, Sweden, Switzerland \\
\hline $10-12$ & Sosnia and Herzegovina, Brazil, Finland, Greece, Luxembourg, Norway, Poland, \\
\hline $7-9$ & Portugal, Slovakia \\
\hline $4-6$ & Albania, Bulgaria, Cambodia, Czechia, Cyprus, Demark, Dominican Republic, \\
& Egypt, Estonia, Iceland, Iran, Latvia, Mali, Malta, Mexico, Montenegro, \\
& North Macedonia, Paraguay, Romania, Russia, Singapore, Thailand, \\
& Turkey, Ukraine, Uruguay \\
\hline
\end{tabular}

Although respondents may use different SNSs, they provided only the SNS they most frequently use. Table 4 presents the most-frequently-used SNSs.

Table 4: Most frequently used SNSs

\begin{tabular}{cccc}
\hline Social networking service & N & $\%$ \\
\hline Facebook & 368 & 58.5 \\
\hline WhatsApp & 93 & 14.8 \\
\hline Instagram & 85 & 13.5 \\
\hline Twitter & 16 & 2.5 \\
\hline
\end{tabular}




\begin{tabular}{cccc}
\hline Google + & 11 & 1.7 \\
\hline WeChat & 10 & 1.6 \\
\hline Snapchat & 9 & 1.4 \\
\hline Viber & 8 & 1.3 \\
\hline Pinterest & 5 & 0.8 \\
\hline Skype & 5 & 0.8 \\
\hline Linkedin & 4 & 0.6 \\
\hline Signal & 2 & 0.3 \\
\hline N/A & 13 & 2.1 \\
\hline
\end{tabular}

The most frequently used SNSs are Facebook, WhatsApp, and Instagram, which are all owned by Facebook, Inc. The remaining SNSs have much lower shares, suggesting a skewed sample as it does not reflect the market shares of SNSs.

In our questionnaire, previously validated items were used and adapted to the context of our study. We measured privacy concerns of SNS users (privacy concerns - PC), their trust in SNS providers (trust in social network providers - TiSP), and perceived regulatory protection of their privacy on SNSs (perceived regulation - PR). Each of these constructs was measured with three items. All items were measured using a 5-point Likert scale from 1 (I strongly disagree) to 5 (I strongly agree). We prepared two versions of the questionnaire, one in English and one in Slovenian. Both English and Slovenian questions for PC and PR were taken from (Fujs et al. 2019), and English questions for TiSP were adapted from (Harrison McKnight et al. 2002). Afterward, translators provided independent translations for TiSP items into Slovenian. The translations were then consolidated. The questionnaire was pre-tested by academic peers and refined according to received feedback. To ensure consistency between both versions of items, Slovenian items were translated back into English and compared with the original English items.

The reliability of the questionnaire was evaluated with Cronbach's alpha coefficient (CA). CA ranged from 0.837 (PC) to 0.879 (PR), indicating good reliability for all measured constructs. Items for individual constructs were aggregated into new construct variables by calculating their means. To compare the means of construct variables for respondents in the post-migrant and settled phases, we conducted an independent samples $t$-test. 


\section{TOPICS DISCUSSED IN ONLINE GROUPS}

Topics related to the pre-migrant phase included seeking information and tips regarding vacations, short-term accommodation, working abroad, housing, or legal advice. It is not possible to determine with certainty for all queries whether potential migrants or tourists posted them. Not all members of online groups on Facebook seem to be current or potential migrants as people interested in the destination country and past migrants also seem to frequent online groups of interest. Several online groups, such as Delo \& nastanitev Slovenci na Dunaju, dedicated to exchanging information on job opportunities and accommodation, have been identified. In these online groups, members mostly look for information and advice regarding working conditions, needed knowledge, and expectations from potential employers. They rarely discuss topics on how to reach the destination, indicating that the travel phase may not be an issue for Slovenian migrants (as opposed to illegal migrants). Also, online groups and websites dedicated to traveling may contribute to this.

Most topics related to the post-migrant and the settled phases seem to be overlapping. The only topic that can relatively confidently be attributed to migrants in the post-migrant phase is seeking different recommendations (e.g., tax advisor, physician, lawyer)'. Otherwise, migrants in these two phases are often looking for information on how to purchase products that are made or are commonly available in Slovenia (e.g., potica) in the destination country. For example, one user wrote: "Where can I buy potica online and have it shipped!!! I miss it 2. ."

Migrants also frequently seek ways to send packets to or receive them from Slovenia. For example, they are looking for people traveling from or to Slovenia who can bring or take back some goods with them:

Would anyone have suggestions on easiest method/carrier to send small package to Slovenia? We are sending some items to our cousins in Topolsica we have met using the information and tools from this group. We are so appreciative for all the sharing and any information about mailing/shipping. Thank you all!

A significant share of posts in online groups is related to the achievements of Slovenian sportsmen and sportswomen, including photos of the various beauties of Slovenia, or is simply related to Slovenia in one way or the other. For example, a user wrote a post on a famous Slovenian architect:

Jože Plečnik was a Slovene architect who had a major impact on the modern identity of the city of Ljubljana, the capital of Slovenia, most notably by designing the iconic Triple Bridge and the Slovene National and University Library building, as well as the

All texts copied from Facebook are in the original (untranslated, uncorrected). 
embankments along the Ljubljanica River, the Ljubljana open market buildings, the Ljubljana cemetery, parks, plazas, etc.

Online group members sometimes post job opportunities and vacancies or try to raise funds for various reasons, such as funerals, building construction, birthday gifts, research, etc. Migrants use online groups to socialize and search for people who are willing to meet (e.g., for a drink or a picnic). In the post-migrant phase, such activities may be aimed at establishing new relationships with other migrants in the destination country. In the settled phase, they may seek to keep or re-establish the connection to people from the homeland and its culture. Some online groups seem to specialize in the promotion of socializing events, such as meetings, picnics, dances, and other social events. Online groups dedicated to helping Slovenian migrants to study their roots and discover their relatives and family in Slovenia (e.g., Slovenian Genealogy Society International, Inc. (SGSI), Slovenian Genealogy (Genealogy2000), Slovenian Genealogy (gen2000) WWII, 1945 and its aftermath) also exist. These groups primarily facilitate the exchange of information between migrants in the settled phase and residents in Slovenia. For example, a user looks for available records online: "Anyone researching Lutheran church records for Prekmurje? Having difficulties locating any records and any suggestions would be appreciated." For similar reasons, residents in Slovenia sometimes publicly search for specific people on online groups.

We can draw several implications from these results. First, the results seem to support existing literature on the use of technology in the migration process (Lenarčič 2020). A much lower frequency of topics related to the travel phase discussed in online groups on Facebook may be attributed to predominantly legal migration of Slovenian migrants and alternative channels for obtaining this information. Second, SNSs can help migrants establish new relationships with migrants in the destination country. Although such relationships cannot replace new relationships with local residents, they may help migrants to avoid or cope with periods of loneliness in the post-migrant phase. It may be important to note that online groups do not seem to be frequented by the local population (e.g., individuals that may be interested in socializing with Slovenian migrants). Third, online groups seem to be an important source of more or less accurate information on the destination (e.g., information related to finding and keeping a job) for potential migrants. Since online groups appear to be well-frequented by potential migrants, they may help them make an informed decision about migration. Fourth, we did not notice any signs of long-distance nationalism or other phenomena that would fuel inter-ethnic tensions between migrants and the local population. Instead, members seem to be more interested in promoting their homeland and culture by sharing posts on, e.g., achievements and beauties related to Slovenia. 


\section{PERCEPTIONS REGARDING SOCIAL NETWORKING SERVICES}

By far, Facebook is the most popular SNS among the respondents, followed by WhatsApp and Instagram. These three SNSs are all owned by Facebook, Inc. Although Facebook is currently the most widely used SNS in the world (Grčić et al. 2017; Ortiz Ángeles et al. 2017; Fujs et al. 2019a), it still stands out, as $86.8 \%$ of respondents use most frequently one of their SNSs. Facebook's domination may be partially attributed to the employed sampling focusing on online groups on Facebook. It may be interesting to note that Facebook was not the most frequently used SNS among respondents from China. A key factor may be that it is banned there (Błachnio et al. 2016). China has developed its own alternative SNSs, such as WeChat, which enable companies to monitor conversations and to detect politically sensitive discussions (Shirky 2011; Harwit 2017). Authoritarian regimes and certain SNSs may, therefore, invade the privacy of SNS users.

Despite considerable efforts by oppressive regimes to censor the internet (e.g., the Great Firewall of China) by employing a combination of automatic censorship with artificial intelligence and manual censorship (Heins 2014), individuals can still access banned SNSs through various proxies, such as Virtual Private Networks (VPNs) or the Tor anonymity network (Xu 2014). Another threat to the privacy of SNS users comes from SNS providers. Major SNS providers, such as Facebook, are built on a business model of selling data of their users in one way or another. By using SNSs, users essentially trust their SNS providers with their personal data (e.g., private chat messages). Although existing regulations, such as the GDPR, may protect SNS users' data to a certain extent, SNS providers did not significantly change their business models, indicating that SNS users may still consider them as threats to their privacy. As a counterweight to state surveillance and profit-maximizing SNSs, several privacy-oriented decentralized SNSs, such as Mastodon, Diaspora, and Riot.im, have emerged. These SNSs aim to keep the ownership of data on the side of their users. However, with a few exceptions limited to certain profiles of users (e.g., Discord in the gamer community), they have not reached a wider user base. A final threat to the privacy of SNS users may stem from the users themselves. Most SNSs enable users to publicly express themselves by posting their thoughts, photos, and other materials. These users' public fingerprints may be used by others, from repressive regimes to potential employers, without the SNS users' knowledge (Miller 2012).

To gain an insight into the overall perceptions of respondents regarding SNSs, Table 5 presents the descriptive statistics of aggregated variables and their reliability coefficients. 
Table 5: Means, standard deviation and Cronbach's alpha of measured constructs

\begin{tabular}{ccccc}
\hline Code & Construct & M & SD & CA \\
\hline PC & Privacy concerns & 4.15 & 0.81 & 0.837 \\
TiSP & Trust in SNS provider & 2.49 & 0.90 & 0.840 \\
PR & Perceived regulation & 2.49 & 0.83 & 0.879 \\
\hline
\end{tabular}

$M$ - mean; $S D$ - standard deviation; $C A$ - Cronbach's alpha

The high mean for Privacy concerns $\left(M_{P C}=4.15\right)$ suggests that respondents do care about privacy, although they may not always be motivated to protect themselves against privacy intrusions (Mihelič, Vrhovec 2018). Most respondents appear to be privacy-aware regarding providing their personal data to SNS providers. In part, this may be attributed to a general rise in privacy awareness after Edward Snowden's leaks of highly classified information from the NSA in 2013, which revealed various global surveillance programs and prompted a discussion on the trade-offs between national security and individual privacy (Lucas 2014). Even though respondents appear to be highly concerned about providing personal data to SNSs, the mean for Trust in SNS provider $\left(M_{\text {TisP }}=2.49\right.$ ) does not appear to be similarly low; it is just under the neutral score of the scale. These results suggest that respondents do not fully trust their SNS providers, which may be a consequence of several recent high-profile privacy-related scandals, such as Cambridge Analytica. These scandals, however, appear to have a more limited impact on the privacy awareness of SNS users than global surveillance programs discussed previously. This could be attributed to surveillance programs monitoring all internet activity beyond the activity on SNSs, such as personal e-mails, advanced tracking of everyday internet activities (e.g., which websites people are browsing), and profiling. Even though SNSs, such as Facebook, diligently try to capture all internet activity of their existing and potential users for profiling purposes (e.g., Facebook-like buttons on websites that do not appear to be connected to Facebook enable it to track their users even when not browsing through Facebook - even when users are not logged in), SNS users are rarely aware of this practice. The mean for Perceived regulation $\left(M_{P R}=2.49\right)$ also seems to be relatively low, indicating that respondents do not consider the regulations ensuring adequate levels of privacy on SNSs. Since respondents reside in different countries with differing regulations, these results need to be considered with caution. Overall, the results suggest that governments, domestic and international legislation do not protect the privacy of SNS users. Two key reasons may cause such perceptions of the respondents. First, governments may be unable to provide regulations for adequate privacy on SNSs due to the international character of the cyberspace and the innovative capacity of SNS providers. Second, governments may be unwilling to provide such regulations as they would, e.g., compromise their ability to ensure national security. For example, the state authorities require all software used on the Russian market to 
provide backdoor access that enables surveillance by state institutions. For cyberspace to become a privacy-friendly environment, international regulations ensuring adequate levels of privacy would have to be established. However, it does not appear that this will happen anytime soon in the foreseeable future.

Table 6 presents the results of an independent samples $t$-test to determine differences between perceptions of migrants in the post-migrant and settled phases.

Table 6: Comparison of construct means in post-migrant and settled phases

\begin{tabular}{llcccc}
\hline Code & Construct & $T$ & $p$ & $M_{p m}\left(S D_{p m}\right)$ & $M_{s}\left(S D_{s}\right)$ \\
\hline PC & Privacy concerns & -2.788 & ${ }^{* *} 0.005$ & $4.01(0.90)$ & $4.21(0.77)$ \\
TiSP & Trust in SNS provider & 0.566 & 0.569 & $2.52(0.84)$ & $2.48(0.93)$ \\
PR & Perceived regulation & 2.349 & ${ }^{*} 0.019$ & $2.61(0.85)$ & $2.44(0.82)$ \\
\hline
\end{tabular}

$p m$ - post-migrant phase; $s$ - settled phase; ${ }^{*} p<0.05,{ }^{* *} p<0.01$

There seems to be a significant difference in privacy concerns $(p<0.01)$ and perceived regulation $(p<0.05)$ of migrants in the post-migrant and settled phases. The results suggest that migrants in the post-migrant phase have lower privacy concerns than migrants in the settled phase. This can be attributed to their higher degree of perceived regulatory privacy. It seems that migrants in the post-migrant phase trust more the regulative protection of their privacy and have lower privacy concerns due to this. Assuming that, with time, migrants become more familiar with the regulations in the destination country, their perceived regulatory protection lowers slightly, resulting in higher privacy concerns. An alternative explanation could be that migrants are simply less concerned about their privacy in the post-migrant phase as other issues, such as adapting to the new environment, take priority. In the settled phase, privacy slowly floats higher on the list of priorities.

\section{CONCLUDING REMARKS}

We did not identify any truly global online group of Slovenes around the world. Even though we were able to find some general online groups, such as Slovenci po svetu, Lastovke stičišče povratnikov, zdomcev in izseljencev, Slovenci.si, Urad Vlade RS za Slovence $v$ zamejstvu in po svetu and Slovenska izseljenska matica, they have relatively few members and do not appear to be particularly active. This finding suggests that online groups do not fully remove borders and are still limited to certain physical locations. A more narrowly focused online group may provide its members with more relevant topics (e.g., topics relevant for Austria may differ significantly from those relevant for Canada). It is not always easy to find online groups related to Slovenes around the world due to varying naming conventions (e.g., Slovenes in 
[...], Slovenians in [...], Slovenci $v$ [...], topic-based names). Some standardization of online group names would be beneficial, however hard to achieve, as group owners can freely choose their groups' names. Alternatively, it would be beneficial to create and maintain a database of Slovenian online groups. More or less updated lists of Slovenian associations around the world already exist, such as Slovenci.si (2019; Urad vlade RS za Slovence $v$ zamejstvu in po svetu 2019). These lists are, however, limited to official associations and do not include informal online groups that can be found on SNSs. An updated database of online groups would help in identifying thriving as well as declining groups.

Slovenian migrants and their descendants are often looking for their relatives. It would be thus beneficial to connect related online groups with various institutes and museums that have access to such data and could help them in their quests. One of the key treasuries in this regard are churches that keep family trees in their baptismal books. Since archives are not always in digital form, it would be critical to motivate people with access to the archives to engage in online genealogical groups. Going online could motivate people with access to the archives to enhance their presence in Slovenia and expand their genealogy business to the global market.

Despite the meaningful implications, the study has some limitations that provide the impetus for future studies in this research area. First, we conducted our study among Slovenian migrants via a survey in two languages (i.e., Slovenian and English). It would be beneficial to conduct the survey also in other languages, such as Spanish (Lapuh 2011). Other languages would enable the inclusion of more Slovenian migrants and their descendants, especially those who speak neither Slovenian nor English. Second, our findings cannot be fully generalized to all Slovenian migrants due to the snowball sampling method employed. This is a limitation that would be next to impossible to overcome as no lists of Slovenian migrants exist. There are electoral registries; however, they are limited only to Slovenian citizens with voting rights, which excludes Slovenian migrants without citizenship. Legislation, such as the GDPR, may make it even more difficult to reach Slovenian migrants in the future. Despite this limitation, conducting surveys may still prove useful, especially when complemented by qualitative research approaches that provide a more in-depth understanding of the phenomena under study (Fujs et al. 2019b). Third, our survey was distributed through online groups on Facebook and by e-mail. Including other SNSs would allow for the comparison perceptions of users of different SNSs as users of certain SNSs may be willing to reveal more information than users of other SNSs (Dwyer et al. 2007).

Future research may also focus on the differences between the perceptions of SNSs users in the East and the West, potentially by applying the institutional theory on the use of SNSs by Slovenian migrants in different countries. Looking more broadly, SNSs themselves present an opportunity for researchers as well. For example, in the past, researchers had to rely on testimonies, diaries, notes, and correspondence to outline the biography of individuals, such as Ivana Kobilca (Strle 2018). With the 
emergence of SNSs, researchers may be able to gain more personal insight into the studied people (Reips, Buffardi 2012). However, data triangulation with other data sources would still be needed to support and confirm the data obtained directly from SNSs. Another avenue for future research lies in examining the evolution of web pages of Slovenes around the world to gain insight if they evolved into or were complemented by online groups on SNSs.

\section{REFERENCES}

Ajder, Teodor (2018). Romanian Diasporic Facebook Groups as Public Spheres. Open Cultural Studies 2/1, 723-734.

Atanasova, Sara, Petrič, Gregor (2014). Spletne skupnosti: Tipologija in temeljne značilnosti. Družboslovne razprave 75, 85-106.

Bieniasz, Jedrzej, Szczypiorski, Krzysztof (2019). Methods for Information Hiding in Open Social Networks. Journal of Universal Computer Science 25/2, 74-97.

Błachnio, Agata et al. (2016). An International Perspective on Facebook Intrusion. Psychiatry Research 242, 385-387.

Bolíbar, Mireia (2020). Social Capital, Human Capital and Ethnic Occupational Niches: An Analysis of Ethnic and Gender Inequalities in the Spanish Labour Market. Palgrave Communications 6/1, 22.

Bustos López, Maritza et al. (2018). EduRP: An Educational Resources Platform Based on Opinion Mining and Semantic Web. Journal of Universal Computer Science 24/11, 1515-1535.

Dwyer, Catherine, Hiltz, Starr, Passerini, Katia (2007). Trust and Privacy Concern Within Social Networking Sites: A Comparison of Facebook and MySpace. AMCIS 2007 Proceedings. Association for Information Systems, Paper 339.

Edelblute, Heather B., Altman, Claire E. (2020). Depressive Symptoms among Mothers with Young Children - the Role of Family Migration and Social Networks in Mexico. Journal of Mental Health, 1-8.

Fujs, Damjan, Mihelič, Anže, Vrhovec, Simon (2019a). Social Network Self-Protection Model: What Motivates Users to Self-Protect? Journal of Cyber Security and Mobility $8 / 4,467-492$.

Fujs, Damjan, Mihelič, Anže, Vrhovec, Simon (2019b). The Power of Interpretation: Qualitative Methods in Cybersecurity Research. Proceedings of the 14th International Conference on Availability, Reliability and Security - ARES '19. New York, USA: ACM Press, 1-10.

Golova, Tatiana (2020). Post-Soviet Migrants in Germany, Transnational Public Spheres and Russian Soft Power. Journal of Information Technology \& Politics, 1-19.

Grčić, Klara, Bagić Babac, Marina, Podobnik, Vedran (2017). Generating Politician Profiles Based on Content Analysis of Social Network Datasets. Journal of Universal Computer Science 23/3, 236-255. 
Harwit, Eric (2017). WeChat: Social and Political Development of China's Dominant Messaging App. Chinese Journal of Communication 10/3, 312-327.

Heins, Marjorie (2014). The Brave New World of Social Media Censorship. Harvard Law Review 127/8, 325-330.

Hiller, Harry H., Franz, Tara M. (2004). New Ties, Old Ties and Lost Ties: The Use of the Internet in Diaspora. New Media \& Society 6/6, 731-752.

Hladnik Milharčič, Mirjam (2008). Internet and the Transformations in Preserving Cultural Heritage in American-Slovenian Ethnic Communities. Dve Domovini / Two Homelands 28, 57-71.

Joinson, Adam N. (2008). 'Looking at', 'Looking up' or 'Keeping up with' People? Motives and Uses of Facebook. Proceeding of the Twenty-Sixth Annual CHI Conference on Human Factors in Computing Systems - CHI '08. New York, USA: ACM Press, 1027-1036.

Kalc, Aleksej (2018). Izseljevanje iz Beneške Slovenije v Severno Ameriko na začetku 20. stoletja na podlagi ladijskih potniških seznamov. Dve Domovini / Two Homelands 47, 107-126.

Kuzmič, Mihael (2001). Slovenski izseljenci iz Prekmurja v Bethlehemu. ZDA 1893-1892: Naselitev in njihove zgodovinske, socialne, politične, literarne in verske dejavnosti (eds. Janja Žitnik, Vojislav Likar). Ljubljana: Inštitut za slovensko izseljenstvo ZRC SAZU.

Lapuh, Lucija (2011). Geografski vidiki sodobnega izseljevanja iz Slovenije. Dela 36, 69-91.

Lee, Jane, Hong, Jeeyeon, Zhou, Yuanjin, Robles, Gabriel (2020). The Relationships between Loneliness, Social Support, and Resilience among Latinx Immigrants in the United States. Clinical Social Work Journal 48/1, 99-109.

Lenarčič, Blaž (2020). Migracijski proces v omrežni družbi. Dve Domovini / Two Homelands 51/1, 167-183.

Lucas, George R. (2014). NSA Management Directive \#424: Secrecy and Privacy in the Aftermath of Edward Snowden. Ethics \& International Affairs 28/1, 29-38.

McKay, Deirdre (2020). Ambient Surveillance: How Care-for-control Emerges across Diasporic Social Media. Ethnos 85/2, 309-326.

McKnight, D. Harrison, Choudhury, Vivek, Kacmar, Charles (2002). The Impact of Initial Consumer Trust on Intentions to Transact with a Web Site: A Trust Building Model. The Journal of Strategic Information Systems 11/3-4, 297-323.

Meden, Ahac (2007). Web Pages of Slovenians across the World. Dve Domovini / Two Homelands 26, 47-73.

Mihelič, Anže, Vrhovec, Simon (2018). A Model of Self-Protection in the Cyberspace / Model samozaščite v kibernetskem prostoru. Elektrotehniški vestnik/Electrotechnical Review 85/1-2, 13-22.

Miller, Daniel (2012). Social Networking Sites. Digital Anthropology (eds. Heather A. Horst, Daniel Miller), 146-161. 
Nelson, Kylee Anne, Marston, Christine (2020). Refugee Migration Histories in a Meatpacking Town: Blurring the Line between Primary and Secondary Migration. Journal of International Migration and Integration 21/1, 77-91.

Oiarzabal, Pedro J., Reips, Ulf-Dietrich (2012). Migration and Diaspora in the Age of Information and Communication Technologies. Journal of Ethnic and Migration Studies 38/9, 1333-1338.

Ortiz Ángeles, Sonia et al. (2017). Electoral Preferences Prediction of the YouGov Social Network Users Based on Computational Intelligence Algorithms. Journal of Universal Computer Science 23/3, 304-326.

Reips, Ulf-Dietrich, Buffardi, Laura E. (2012). Studying Migrants with the Help of the Internet: Methods from Psychology. Journal of Ethnic and Migration Studies 38/9, 1405-1424.

Rowan L. F. ten, Kate, Bilecen, Başak, Steverink, Nardi (2020). A Closer Look at Loneliness: Why Do First-Generation Migrants Feel More Lonely than their Native Dutch Counterparts? The Gerontologist 60/2, 291-301.

Shahriari, Mohsen, Haefele, Sabrina, Klamma, Ralf (2017). Using Content to Identify Overlapping Communities in Question Answer Forums. Journal of Universal Computer Science 23/9, 907-931.

Shirky, Clay (2011). The Political Power of Social Media. Foreign Affairs 90/1, 28-41.

Sivasangari, V., Mohan, Ashok Kumar, Suthendran, Kannan, Sethumadhavan, M. (2018). Isolating Rumors Using Sentiment Analysis. Journal of Cyber Security and Mobility 7/1, 181-200.

Slovenci.si (2019). Seznam društev v posamezni državi. Moja Slovenija: Slovenske zgodbe iz sveta in domovine.

Statista (2020), Global digital population as of January 2020, https://www.statista.com/ statistics/617136/digital-population-worldwide/ (2. 3. 2020).

Strle, Urška (2018). V preseku mobilnosti in socialnih mrež: Biografska skica Ivane Kobilca. Dve Domovini / Two Homelands 48, 147-162.

Urad vlade RS za Slovence v zamejstvu in po svetu (2019). Slovenci po svetu.

Wang, Zhiling (2020). The Incompatibility of Local Economic Prosperity and Migrants' Social Integration: Evidence from the Netherlands. The Annals of Regional Science 64/1, 57-78.

Xu, Beina (2014). Media Censorship in China. Council of Foreign Relations 25.

Zhang, Hongxia, Qin, Su, Guiqiang, Qiao, Yin, Yingmei, Wu, Xiaoxiao, Xie, Wujie (2019). Local-Migrant Interaction in Everyday Life in an Ancient Tourism Town. International Journal of Environmental Research and Public Health 17/1, 266. 


\section{POVZETEK}

\section{UPORABA STORITEV SOCIALNIH OMREŽIJ MED SLOVENCI PO SVETU Damjan FUJS, Simon VRHOVEC}

V preteklosti razmere prenekaterima Slovencu ali Slovenki niso prizanašale in so bile povod za odhod v svet. V iskanju boljšega življenja so odhajali z malo ali nič informacijami o destinaciji. Danes so migracije drugačne, s pomočjo storitev socialnih omrežij (SSO) se v relativno kratkem času lahko pridobi informacije, napotke in usmeritve za delo $v$ tujini.

V prispevku avtorja poročata o eni prvih študij o uporabi SSO med slovenskimi migranti v različnih fazah migracijskega procesa. Migracijski proces se deli na štiri ključne faze: predmigracijska faza, faza potovanja, postmigracijska faza in ustaljena faza. Da bi dobila vpogled v teme, o katerih slovenski migranti razpravljajo v različnih fazah migracijskega procesa, sta najprej pregledala spletne skupine na Facebooku $(N=270)$. Nato sta, da bi ugotovila razlike med percepcijami o SSO slovenskih migrantov v postmigracijski in ustaljeni fazi, med njimi izvedla anketo $(N=629)$. Rezultati pregleda spletnih skupin na Facebooku podpirajo obstoječo literaturo o uporabi tehnologije $v$ migracijskem procesu. Manjšo pogostost tem, povezanih s fazo potovanja, je mogoče pripisati pretežno zakonitim migracijam slovenskih migrantov in alternativnim kanalom za pridobivanje informacij o potovanjih. SSO lahko migrantom pomagajo pri vzpostavljanju novih odnosov z migranti v namembni državi. Čeprav taki odnosi ne morejo nadomestiti novih odnosov z lokalnimi prebivalci, pa lahko priseljencem pomagajo, da se izognejo obdobjem osamljenosti v postmigracijski fazi ali da se z njimi spopadejo. Spletnih skupin lokalno prebivalstvo praktično ne obiskuje, zato preko njih migranti ne morejo navezati stikov z lokalnim prebivalstvom. Spletne skupine se zdijo za potencialne migrante pomemben vir bolj ali manj natančnih informacij o destinaciji (npr. informacije o iskanju in ohranjanju zaposlitve). Ker se zdi, da potencialni migranti pogosto sodelujejo v spletnih skupinah, jim te lahko pomagajo pri odločitvi o migraciji.

V študiji avtorja nista opazila nobenih pojavov, ki bi spodbujali etnične napetosti med migranti in lokalnim prebivalstvom. Člani spletnih skupin so namreč bolj zainteresirani za promocijo svoje domovine in kulture, npr. z deljenjem objav o dosežkih in lepotah Slovenije. Rezultati ankete med slovenskimi migranti podajajo nekatere nove ugotovitve. Visoka skrb za zasebnost nakazuje na to, da je respondentom zanjo mar. Rezultati kažejo tudi, da slovenski migranti ponudnikom socialnih omrežij ne zaupajo povsem in da se jim z zasebnostjo povezana regulativa ne zdi zadostna. Primerjava med odgovori migrantov v postmigracijski in ustaljeni fazi nakazuje, da imajo migranti v postmigracijski fazi manjše skrbi glede zasebnosti in zaznavajo višjo regulativno zaščito svoje zasebnosti kot $v$ ustaljeni fazi. V zaključku so podane praktične implikacije raziskave in napotki za prihodnje raziskave. 